\title{
Biological monitoring of lotic ecosystems: the role of diatoms
}

\author{
Bere, $T$ * and Tundisi, JG. \\ Instituto Internacional de Ecologia - IEE, \\ Rua Bento Carlos, 750, Centro, São Carlos, SP, Brazil \\ *e-mail: taubere@yahoo.com \\ Received February 10, 2009 - Accepted June 18, 2009 - Distributed August 31, 2010
}

\begin{abstract}
Increasing anthropogenic influence on lotic environments as a result of civilisation has captured public interest because of the consequent problems associated with deterioration of water quality. Various biological monitoring methods that provide a direct measure of ecological integrity by using the response of biota to environmental changes have been developed to monitor the ecological status of lotic environments. Diatoms have been used extensively in this regard and this review attempts to summarise the basic concepts associated with biological monitoring using benthic diatoms. Where possible, examples from work carried out in Brazil are used.
\end{abstract}

Keywords: biological monitoring, lotic environment, benthic diatoms.

\section{Biomonitoramento dos ecossistemas lóticos: o papel das diatomáceas}

\section{Resumo}

O aumento da influência antropogênica sobre ambientes lóticos como resultado da civilização conquistou o interesse público por causa de problemas relacionados com a consequente deterioração da qualidade da água. Vários métodos de biomonitoramento que fornecem uma medida direta da integridade ecológica usando a resposta da biota a alterações ambientais têm sido desenvolvidos para monitorar o estado ecológico de ecossistemas lóticos. Diatomáceas têm sido amplamente utilizadas e esta revisão tenta resumir os conceitos básicos associados ao monitoramento biológico utilizando diatomáceas bentônicas. Sempre que possível, exemplos de trabalhos realizados no Brasil serão utilizados.

Palavras-chave: biomonitoramento, ecossistemas lóticos, diatomáceas bentônicas.

\section{Introduction}

Lotic environments are fundamental components of regional and global biogeochemical cycles, acting as both transport pathways and sites of elemental transformations and storage and they act as sources of drinking water, fisheries resources, irrigation supplies, and waste removal systems. They are characterised by interactions among physical, chemical and biological processes, which reach a higher degree of complexity downstream (Wehr and Descy, 1998).

The fundamental feature of lotic systems is that activities or disturbances at one location affect processes and organisms downstream, complicating the management of these systems. The systems are also characterised by longitudinal differences in the time scales of chemical and biological processes rendering it difficult to design polices and assess the results of management actions (Tundisi and Matsumura-Tundisi, 2008). Characterising and managing dynamic environmental conditions in heterogeneous systems such as these, therefore, requires innovative approaches, with the management process striking a balance between human needs and ecological integrity (Edwards, 1995; Tundisi and Matsumura-Tundisi, 2008).
Ecological principles are now playing an important role in the management of these systems.

High population densities and multiplicity of industrial and agricultural activities expose most hydrographic basins to heavy and rising environmental impacts especially to pollution by domestic and industrial waste residues (Salomoni et al., 2006). This increasing anthropogenic influence on lotic environments that parallels civilisation has captured public interest because of the consequent deterioration of water quality, health problems, pest plants and animals, and other problems (Salvia et al., 1999; Bere, 2007). The purpose of this review is to summarise the basic concepts associated with biological monitoring using benthic diatoms. Where possible, examples from work carried out in Brazil are used.

\section{Approaches to Monitoring the Ecological Status of Lotic Systems}

Two threads of basic approaches to the assessment of water quality deterioration in lotic systems run through 
the literature. The first approach involves the assessment of physical and chemical variables of lotic systems in order to gain some insight into their water quality. In most cases, this method allows only instantaneous measurements, therefore restricting the knowledge of water conditions to the period when the measurements were taken. The chemistry at any given time is a snapshot of the water quality at the time of sampling ignoring temporal variation of water quality variables that is usually high in lotic environments (Rocha, 1992). Sophisticated chemical analytical methods have been developed but still they cannot identify and quantify pertinent compounds, especially synthetic organic compounds that are highly toxic (Aidar and Sigand, 1993).

The second approach involves use of biological methods (biological monitoring), the theory behind which is to provide a direct measure of ecological integrity by using the response of biota to environmental changes (Karr, 1991). This allows long-term environmental effects to be detected because of the capacity of reflecting conditions that are not present at the time of sample and analysis. The key to use of the aquatic biota as reliable indicators of the changes in lotic environmental conditions is deciphering the integrated environmental information in species rich assemblages (Pan et al., 1996).

Biological monitoring has gained momentum in aquatic health management programmes due to several shortcomings in standard physical and chemical methods described above. Biological monitoring is now viewed as an ideal means by which progress towards integrated water resources management can be monitored in that it provides a summary of conditions, rather like temperature and blood pressure are used to measure human health (Walmsley, 2000). Biological monitoring is now an important branch of applied ecology where the scientific and economic interests of our society meet in the management of lotic systems (Passy, 2007).

Physical and chemical methods are, however, complimentary to biological methods, contributing to the correct assessment of the quality of running waters (Lobo et al., 2004a). Since the biological response is to the integrated physical and chemical environment to which the organism has been exposed for some time, it is not surprising that the physical and chemical indicators often do not correlate with biological indices (Schoemann, 1979; Round, 1991).

\section{Biotic Indices}

The patterns of biota inhabiting lotic systems are responsive to the nature of the physical and chemical characteristics of these systems (Karr, 1991). The integrity of biota inhabiting lotic ecosystems thus provides a direct, holistic and integrated measure of the integrity of the systems. To this effect, therefore, the ultimate monitor of aquatic systems is the aquatic life itself (John, 2000). It is on this basis that biotic indices enjoy widespread use in the assessment of the ecological status of lotic ecosystems.

Several indices of biotic integrity have been developed worldwide to assess the health status of the lotic systems. These indices make use of the niche requirements and habitat preferences of the individual species (autecology), a population (synecology) or higher taxonomic groupings to infer environmental conditions in an ecosystem (Stoermer and Smol, 1999). Long-term data gathered on the tolerances of a species are used to compile an index that can, in turn, be used to deduce environmental conditions from the species composition by taking into account the specific tolerances of the species in the community surveyed (Patrick, 1986; de la Rey et al., 2008). These indices can be constructed to measure specific pollutants or general environmental conditions.

Many indices have been developed using fish, macroinvertebrates, zooplankton and phytoplankton and especially benthic diatoms. A comparison of three indices of water quality (chemical, zoological and botanical assessment using diatoms) concluded that the latter gave the most precise data (Leclercq and Maquet, 1987) though in some cases, aquatic macroinvertebrates have been demonstrated to be superior to diatoms as biological indicators, with a capacity to reflect on sedimentation in the river bed that cannot be reflected by diatoms (Schoeman and Haworth, 1986; Katoh, 1992; Prygiel and Coste, 1993). In the cases of intermediate ranges of pollution where the diatoms and macroinvertebrates are less sensitive, chemical analysis has been shown to be more efficient (Leclercq and Maquet, 1987; Schoeman and Haworth, 1986).

\section{Distribution of Diatoms in Lotic Systems}

A fundamental part of lotic ecosystems is the periphyton community assemblages whose diversity increases as anthropogenic influences on the system increase (Archibald, 1972; Lobo and Kobayasi, 1990; Round, 1991). This is consistent with the intermediate disturbance hypothesis (Connell, 1978), which states that the highest diversity is maintained at intermediate levels of pollution. These assemblages have important implications for ecosystem processes in lotic environments. Firstly, they are an integral part of the energy cycle in nearly all lotic ecosystems providing much of the food and thus maintaining higher trophic levels i.e. they are important for establishment of ecological balance (Rocha, 1992).

Secondly, they purify waters by absorbing many impurities such as nutrients and heavy metals and are sites of the breakdown of bacterial and other organic matter contamination. Thirdly, they respond rapidly to degradation of water quality, often changing in both taxonomic composition and biomass where even slight contamination occurs (Rocha, 1992; Patrick and Hendrickson, 1993; Biggs and Kilroy, 2000; Doung et al., 2007). They also play an important role in global cycling of silica and 
carbon (Mann, 1999). The maintenance of proper community structure and functioning of periphyton assemblages in lotic systems in the face of encroaching human development and climate change, among other threats is, therefore, important in river health management.

A major part of these periphyton assemblages is made up of diatoms which are various microscopic one-celled or colonial members of the algal division or phylum Bacillariophyta, of the class Bacillariophyceae, having cell walls of silica consisting of two interlocking symmetrical valves. They are universally distributed in all types of aquatic environment with others being endemic to specific regions (Potapova and Charles, 2003). They multiply rapidly, maintaining a dynamic population of varying size depending on the prevailing environmental conditions. Diatoms are the most species rich group of algae with tens of thousands of species (Mann, 1999). Round (1991) states that there are currently over 260 genera of living diatoms with over 100,000 species.

Multiple factors prevailing at different temporal and spatial scales play an important role in structuring benthic diatom communities in lotic systems (Potapova and Charles, 2002; Moura et al., 2007), with local environmental conditions playing a more important role compared to broad-scale climatic, vegetational and geographical factors (Pan et al., 1996). Our comprehension of the role of temporary factors in shaping global communities is, however, still in its infancy (Passy, 2007).

Some of the factors most often found to be important in shaping the distribution patterns of benthic diatoms in lotic systems are water chemistry (particularly $\mathrm{pH}$, ionic strength and nutrient concentrations), substrate, current velocity, light (degree of shading) grazing, temperature (which also correlates strongly with latitude and altitude) (Patrick and Reimer, 1966; Round, 1991; Pan et al., 1996; Potapova and Charles, 2002; Necchi-Júnior, 2003). Most of these factors depend strongly on climate, geology, topography, land-use and other landscape characteristics, and therefore diatom communities are similar within ecological regions defined by these characteristics (Pan et al., 1996). Short-term differences in community composition are also driven by immigration of cells, differences in growth rate between populations and loss processes such as death, emigration and sloughing.

Changes in any of the factors described above, however, need not necessarily bring about the death of some algal species so long as the changes remain within the limits of tolerance of the species. On the contrary, these changes will inhibit the multiplication of some of the species originally present, and encourage that of others, so that primarily the association, that is the percentage composition and not the flora as such, will be changed (Pan et al., 1996).

Diatoms are 'subcos-mopolitan', i.e. they occur anywhere in the world if certain environmental conditions are fulfilled (Kelly et al., 1998). This concept suggests that geographical location is not the determining factor in the distribution of diatom species and the composition of communities, but it is rather the specific environmental variables at a specific site that determine this distribution. Coupled with this also is the recent discovery of the ubiquity-biogeography transition, where organisms smaller than about $1 \mathrm{~mm}$ occur worldwide wherever their required habitats are realised (Finlay, 2005).

A key issue in understanding the patterns of diatom distribution is that of understanding the extent to which they are constrained by geographical factors that limit species dispersal vs. the extent to which they are limited only by the ability of the species to grow under a specific combination of environmental factors (Potapova and Charles, 2002). Is a species not in a particular habitat only because it was not dispersed there or because, though it might have reached the habitat, the environmental conditions were unsuitable for it to survive and compete? Conversely, is a species in a specific location only because it can compete better under those particular environmental conditions, or might it be there simply because it reached a site and its potential competitor did not? Factors influencing dispersal should be clearly understood.

\section{Diatoms and Biological Monitoring of Lotic Systems}

The relation between diatoms and environmental variables are robust and quantifiable making diatoms appropriate quantitative indicators of ecological conditions in lotic systems (Pan et al., 1996; Oliveira et al., 2001). The relationship has been found to be even stronger than those from lentic environments (Round, 1991). Each particular species relate very closely to other species and requires different structural, physical and chemical characteristics intrinsic to its habitat. Whenever these characteristics are subject to variations, the composition of the niche is affected; species vary in their sensitivity and those more resistant to environmental changes either caused by natural fluctuations or by human activities may be favoured by selection (Rocha, 1992).

Understanding the relation of geographical and environmental factors to diatom distribution is important to the process of developing diatom-based water quality indicators. Differences in diatom species composition among geographical areas, caused not only by environmental variation, but also by historical processes of species dispersal and colonisation, add difficulty in applying uniform methods for water quality assessment using diatoms (Potapova and Charles, 2002). Reliable diatom metrics development requires careful investigation of data sets in terms of the major environmental gradients underlying species composition.

Considering the complexity of factors affecting species composition of benthic diatoms, it is advisable that diatom-based river metrics should first be developed for limited geographical areas with the most uniform environmental variables possible (Potapova and Charles, 2002). This still needs to be done very carefully factoring 
in natural variation. Even if communities are developed in very similar environments, there is considerable variation (30-35\%) in the number of species and percent of dominant species attributed to unaccounted-for natural factors and this can be easily mistaken for the effects of the perturbation under study (Patrick and Hendrickson, 1993). Unaccounted-for natural variations and probably simply random fluctuations are important factors affecting community structures that have not always been allowed for when evaluating differences between communities leading to erroneous interpretations. Correlations among environmental factors that determine diatom community structures should be taken into account for the best outcome in biological monitoring studies, because these internal correlations of environmental factors in a data set can lead to incorrect conclusions about species environmental requirements.

Despite all this, however, diatoms represent outstanding bio-indicators for different degrees of pollution. They provide excellent indicators of water quality, especially with widespread increase in eutrophication (Descy and Coste, 1991; Lobo et al., 1999; Rodrigues and Lobo, 2000; Oliveira et al., 2001; Wetzel et al., 2002; Lobo et al., 2002, 2003, 2004a,b,c,d,e; Hermany et al., 2006; Salomoni et al., 2006; Dupont et al., 2007). The large number of species with distinct range of habitats and tolerance to environmental conditions make diatoms the ideal ecological indicators with a wide range of applications both as living organisms and fossils (John, 2000).

Round (1993) lists numerous reasons why diatoms are useful tools of biological monitoring, amongst which are the following: methods are cost effective, data is comparable, and techniques are rapid and accurate. Benthic diatoms have also been deemed to be excellent organisms for biological monitoring because they lie at the base of aquatic food webs and are among the first organisms to respond to environmental change (Lavoie et al., 2008). They also have a short life cycle allowing rapid response to environmental stress especially eutrophication providing detailed information on nutrient changes (Sonneman et al., 2001; Lobo et al., 2004a,b,c,d,e; Billinger et al., 2006; Resh, 2007). A strong correlation between diatom community composition and total nitrogen and total phosphorus has been demonstrated (Winter and Duthie, 2000). Relationships between benthic stream diatom community composition and total phosphorus are strongest at low to medium concentrations $\left(<0.085 \mathrm{mg} . \mathrm{L}^{-1}\right.$, Pan et al., 1996; <0.1 mg.L ${ }^{-1}$, Winter and Duthie, 2000).

Nutrient concentrations, particularly phosphorus, increase with urban development, associated with storm water run-off and are caused by other catchment activities such as agriculture (Sonneman et al., 2001). Studies of streams draining urban centres with mixed storm water and sewage impacts have shown declines in diatom species richness associated with high loads of organic pollution (Lobo et al., 1995a). Changes in water quality associated with urbanisation - judged small to moderate using chemical measurements - are associated with profound changes in biotic community composition of diatoms (Sonneman et al., 2001)

Many field experimental methods have also been designed worldwide to assess the ecological integrity of lotic systems using diatoms. Different methods of manipulating nutrients, for example, have been developed (e.g. Peterson and Stevenson, 1989; Prygiel et al., 1999). The objective of all these methods is to supply varied levels of nutrients to monitor the subsequent growth and productivity (biovolume or biomass assessment) of diatoms, with those species responding to nutrient addition being considered to be growing sub-optimally in the natural habitats. Another technique involves the transfer of colonised substrate (stones, glass etc.) from on site (e.g. polluted) to another site (e.g. non-polluted) followed by monitoring of changes in flora.

Some investigations have also been carried out on the effects of $\mathrm{pH}$, conductivity and trace metals on diatoms (e.g. Lobo et al., 1996; Pen et al., 1996; Oliveira et al., 2001; Sonneman et al., 2001; Potapova and Charles, 2002, 2003; Lobo et al., 2004a; Billinger et al., 2006; Salomoni et al., 2006). Monitoring the changes in $\mathrm{pH}$ and the ionic composition is carried out by simple observation of shifts in the dominant taxa or by inferring ion concentrations or conductivity, using reported optima and some numerical procedures e.g. weighted averaging. The quantification of species responses to concentrations of major ions in fresh water would significantly enhance this (Potapova and Charles, 2002).

\section{Brief History of the use of Diatoms in Biological Monitoring}

The assessment of water quality conditions in freshwater habitats using benthic diatoms dates back to as early as the beginning of the 1900 century when Kolkwitz and Marsson (1908) first attempted to use diatoms as indicators of pollution in aquatic environments. Their study showed that water conditions determined algal communities in aquatic environments but made no efforts to define the various habitats in which the diatoms grow. They developed firstly the Saprobic system - the Saprobity index - that was modified by Liebmann (1951) and Pantle and Buck (1955) which gives values to the species present in the system under consideration in relation to levels of pollution. Their research forms the basis of most subsequent studies on the use of diatoms for biological monitoring.

Patrick (1953) created a biological indicator system, based on changes in energy flow; the system classified water as clean, polluted, very polluted and typical. Slãdeckova and Sládecék (1963) developed a biological indicator system based on periphyton believing that these organisms, being independent of water movement because they are able to adhere to a variety of substrates, might adapt to environments changes more easily than phytoplankton. 
Palmer (1969) created a system that uses algae as biological indicators of pollution. He suggested numbers for each genus of algae as an indication of pollution level - based on extensive study. Other work also used indicative scores (Thunmark, 1945; Nygaard, 1949; Edwards et al., 1972).

The use of indices to assess water quality was also attempted by Zelinka and Marvan (1961) and Slàdecek (1973, 1986), but Descy's work (1979) is given most credit. These studies revealed the need for detailed studies on the tolerance of individual species by actual sampling and relationship to chemical data, rather than relaying on statements in literature. Leclercq and Maquet's (1987) work provide the most complete comparison of chemical invertebrate and diatom indices. Kobayasi and Mayama (1989), working in the rivers of Tokyo, classified diatoms along gradients of organic pollution in to the following categories: i) more tolerant; ii) less tolerant and iii) more sensitive to pollution.

At present, there is a lot of recorded or published data available on diatom ecology and their application to biological monitoring. They are used, for example, in Europe (Sladecek, 1973; Descy, 1979; LangeBertalot, 1979; Kelly and Whitton, 1995; Kelly et al., 1998; Prygiel et al., 1999), North America (Lowe and Pan, 1996; Stevenson and Pan, 1999), Central America (Silva-Benavides, 1996a,b; Michels-Estrada, 2003), South America (Lobo et al., 1998; Loez and Topalian, 1999; Gómez and Licursi, 2001; Lobo et al., 2002 and 2004a,b,c,d,e; Salomoni and Torgan, 2008) Australia (John, 1998, 2000; Chessman et al., 1999), Asia (Watanabe et al., 1988; Kobayasi and Mayama, 1989; Lobo et al., 1995b; Rothfritz et al., 1997) and Africa (Schoeman, 1979; Pieterse and Van Zyl, 1988; Gasse et al., 1995; Bate et al., 2004; Teylor et al., 2007; de la Rey et al., 2007 and 2008). Some of the studies are focused on inferring past hydrochemical characteristics of lakes, while others are designed to monitor present-day conditions in lotic ecosystems.

These attempts have had varying degrees of success (Kelly, 1995). Round (1991) noted three features that have confused the use of diatoms in biological monitoring of lotic systems. Firstly there are semantic problems in which language and translation and writing in languages other than one's own has led to confusion that manifests itself in the proliferation of terminology that is mere variations of expressing the same thing. Secondly, there is an almost total lack of appreciation of microhabitats with their characteristic floras.

Thirdly, there is excessive searching for and counting of numbers of cells (valves) of species, resulting in lengthy lists of diatoms. This is often compounded by dubious academically rigorous pseudo-mathematical manipulations that are not in any way cost effective and, as Fryer (1987) puts it, numbers are increasingly being used as a substitute for real explanations.

Whereas mathematical analyses, whether models or indices, are important in calling attention to differ- ences between populations, elucidation of the causes of observed patterns of diatom assemblages require other supportive data. Knowledge of the autoecology of constituent species needs to be incorporated in making statements concerning pollution levels in various areas. In many instances, similarity indices, ordination techniques and so on are used, but usually not discussed in any detail and sometimes based on inadequate sampling and identification.

Many people have stated that they count 200, 400, or 1,000 specimens without giving the rational for terminating the count. Statement about diatom communities based on small counts may be inaccurate. One should determine how many specimens are to be counted by the use of the asymptote curve or the log normal or some other statistical method to be sure that the community is well represented and that the dominance of the count is characteristic of the community (Patrick, 1986). An important conclusion is that the structure of diatom assemblages is more often characterised by the presence of one or a few, very abundant species and a rather limited number of rare species (Round, 1991), so it is not necessary to have some of the high counts recorded in some of the literature.

\section{Natural and Artificial Substrate Sampling}

Two major approaches to the use of diatoms for assessment of the ecological integrity of lotic systems are generally used worldwide. The first approach involves direct sampling of natural substrate - the favourite being epilithon, while the second approach involves sampling of artificial substrate placed in water - the most used being glass (Round, 1991).

Direct sampling of stone has no a priori recommendations and has the following advantages: 1) ability to find stones in most reaches of the river; 2) stability of the substratum and flora and its presence at all times of the year; 3) growth is not constant throughout the year but this affects only the total biomass and not the overall occurrence of indicator species; 4) recovery of flora after denudation by floods is rapid; 5) flora of the rock surface integrates the effects of variation in water quality over time; and 6) sampling is easy and there are large numbers of cells per $\mathrm{cm}^{2}$ and removal is easy (Descy and Coste, 1991, Leclercq and Manquet, 1987).

Direct sampling has the following disadvantages: 1) in silted lowland rivers stones are often thickly coated with silt that modifies or eliminates the eplithic flora; 2) it is not always easy to sample concrete and bad rock; 3) in torrential upper stretches sampling can be difficult and often the flora is depleted; and 4) shading by surrounding vegetation reduces species richness and biomass. Overall, however, the epilithon does provide an excellent sample of diatom species at most points in a river and is an excellent community for monitoring changes in the environment (Round, 1991). 
Diversity and productivity of diatoms vary from one rock type to another depending on the nature of the physical and chemical properties of the rock. Large stones are expected to have stable communities, whilst small ones may be so moved during periods of high flow that the flora is reduced (Marker and Willoughby, 1988). A careful consideration of these factors during sample collection and subsequent data interpretation is, therefore, necessary as ignoring them is likely to lead to biased results.

The use of artificial substrate (glass slides, bricks, cotton threads e.t.c) has the advantage that the flora can be observed directly, the substratum is standard at all sampling sites and the time for exposure can be controlled (Round, 1991). The disadvantages are, however, overwhelming: 1) they require apparatus to be fixed in the river and there are often losses; 2) there is need to experiment to obtain the optimum time of exposure and often 4 or even 8 weeks is necessary, preventing a rapid estimation of water quality such as can be obtained within hours of sampling the epilithon directly; 4) the floral is an artificial assemblage selected by smooth slide and perhaps by differences due to positioning of slides in relation to the currents; 5) the smooth surface often results in sloughing of the community; and 6) random sampling is not allowed (Descy and Coste, 1991). Recently Salomoni et al. (2008) developed a gadget for sampling epilithic diatoms which consists of a polythene cylinder that is left to float on the surface of the water to which stone substrate is attached. This gadget appears to be more natural than other substrates used.

\section{Diatoms and Biological Monitoring in Brazil}

In Brazil, pioneer studies on phytoplankton in lotic systems were carried out in the Amazonian region rivers (Dickie 1881). First studies on the use of aquatic biota, particularly phytoplankton, for monitoring of the ecological status of lotic systems were carried out in the catchment areas of São Paulo City by a French researcher, Henric Charles Potel, between 1907 and 1910 (Rocha, 1992). This work remained unpublished until translated to Portuguese and published by Branco (1964) and formed the basis of most subsequent studies. Although they were based on empirical and qualitative data, these subsequent studies are extremely important since they constitute the only records of studies on river basins, reservoirs and sources of water supply at that time (Rocha, 1992). Limited data could be gathered at that time due to inadequate infrastructure, lack of skilled personnel and poor policies or strategies for environmental management (Rocha, 1992).

Other studies followed up this work based on quantitative data. All these studies confirmed diatoms as excellent indicators of environmental conditions in lotic system (Lobo and Torgan, 1988; Rosa et al., 1988; Lobo et al., 1991, 1995b, 1996; Lobo and Callegari, 2000, Lobo et al., 2004a,b,c,d,e; Burliga et al., 2005; Lobo et al., 2006; Hermany et al., 2006; Schneck et al.,
2007; Salomoni et al., 2008). In South America in general, Gómez and Licuirsi (2001) published a regional water quality evaluation index for rivers and streams in the Pampas of Argentina, Pampean Diatom Index (PDI) based on the sensitivity of epipelic diatoms to organic enrichment and eutrophication.

In most cases, however, the assessment of the ecological conditions of lotic systems was determined by foreign methods (eg., Lange-Bertalot, 1979; Watanabe et al., 1990; Kobayasi and Mayama, 1989), because no information on pollution tolerant diatoms in Brazilian rivers was present. This direct adoption of these indices can lead to erroneous interpretation of water quality because there are limited overlaps in species composition between two regions, or at least some ecological characteristics of the key taxa vary among the regions (Pan et al., 1996). The occurrence of endemic diatoms further complicates the situation necessitating the compilation of a diatom index unique to the region (Taylor et al., 2007). This underlines a clear vision to develop a biological monitoring protocol that is unique to Brazil.

This prompted the first attempts to classify diatoms in terms of tolerance of species to organic pollution in rivers in southern Brazil by Lobo et al., (1996). Subsequently, Lobo et al. (2002) determined the tolerance to organic pollution of diatom species in different conditions of pollution of lotic systems in Guaiba, RS, and they came up with 3 groups of diatoms: Group A (species more tolerant to pollution), Group B (species tolerant to pollution) and Group C (species less tolerant to pollution), each of which were assigned the following saprobic values $4 ; 2.5$ and 1 respectively.

Based on this information Lobo et al., (2002) developed the first saprobic system in the country, which uses epilithic diatoms for water quality assessment in southern Brazil. This study was completed by Lobo et al., (2004a) leading to the formation of Biological Index of Water Quality (BIWQ) trophic index. This was the first index to be published in rivers of Brazil and it incorporates the effects of organic contamination from the classification described in Lobo et al. (2002), and eutrophication from the values obtained using techniques of multivariate analysis.

Recent studies of environmental monitoring, using the community of diatoms algae in water systems of Guaíba, RS, have demonstrated clear evidence of eutrophication (Lobo et al., 1999; Lobo et al., 2002, 2003, 2004a,b,c,d,e; Oliveira et al., 2001; Rodrigues and Lobo, 2000; Wetzel et al., 2002; Hermany et al., 2006; Salomoni et al., 2006; Dupont et al., 2007). However, the studies are concentrated or restricted mainly to the southern part of the country (Tundisi, 2006), and very little has been done in other lotic systems. For this reason, there is lack of capacity in the form of data, which hampers the full understanding and subsequent management of the lotic systems in other regions of the country and lotic environments in general. 


\section{Conclusion}

Diatoms have an important role in the biological monitoring of lotic ecosystems. Building on the existing data from past studies, especially in the southern part of Brazil, there is a promising future for using diatoms for characterisation and monitoring of ecological conditions in other parts of Brazil.

Acknowledgements - This paper is part of an on-going investigation into the use of diatoms for use in biological monitoring of streams around São Carlos -SP, Brazil. This study is being funded by the Third World Academy of Science (TWAS) through the Conselho Nacional de Desenvolvimento Científico e Tecnológico (CNPq). We also wish to thank the Instituto Internacional de Ecologia management and staff for their support during the course of this study.

\section{References}

AIDAR, E. and SIGAND, TCS., 1993. The effects of chemicals on marine phytoplankton: is predation possible? In CORDEIRO-MARINO, M., AZEVEDO, MTP., SANT'ANNA, CL.,TOMITA, NY. and PASTINO, EM. (Eds.). Algae and environment: a general approach. São Paulo: Sociedade Brasileira de Ficologia; CETESB. p. 65-82.

ARCHIBALD, RM., 1972. Diversity in some South African diatom associations and its relation to water quality. Water Research, vol. 6, no. 10, p. 1229-1238.

BERE, T., 2007. The assessment of nutrient loading and retention in the upper segment of the Chinyika River, Harare: implications for eutrophication control. Water SA, vol. 33, no. 2, p. $279-284$

BIGGS, BFF. and KILROY, C., 2000. Stream priphyton monitoring manual. Christchurch: NIWA. BILLINGER, BJ., COCQUYT, C. and O'REILLY, M., 2006. Benthic diatoms as indicators of eutrophication in tropical streams. Hydrobiologia, vol. 573 , no. 1 , p. $75-87$.

BRANCO, SM., 1964. Henri Charls Potel e a biologia das águas de São Paulo. Revista DAE, vol. 22, no. 2, p. 51-55.

BURLIGA, AL., TORGAN, LC., NOBREGA, EA., BEAUMORD, AC., COSTA, CO. and YAMAUTI, DV., 2005. Diatomáceas epilíticas do rio Itajaí-Mirim, Santa Catarina, Brasil. Acta Scincia Biologia Scintifica, vol. 27, no. 4, p. $415-421$.

CHESSMAN, B., GROWNS, I., CURREY, J. and PLUNKETTCOLE, N., 1999 Predicting diatom communities at the genus level for the rapid biological assessment of rivers. Freshwater Biology, vol. 41, no. 2, p. 317-331.

CONNELL, JH., 1978. Diversity in tropical rain forest and coral reefs. Science, vol. 199, no. 4335, p. 1302-1310.

DESCY, JP. and COSTE, M., 1991. A test of methods for assessing water quality based on diatoms. Verhandlungen der Internationalen Vereinigung für theoretische und angewandte Limnologie, vol. 24, no. 4, p. 2112-2116.

DESCY, JP., 1979. A new approach to water quality estimation using diatoms. Nova Hedwigia, vol. 64, no. 4, p. 305-323.

DICKIE, G., 1881. Notes on the algae from the Amazons and its tributaries. In SOARES, MCS., SOPHIA, MD. and HUSZAR, VM., 2007. Phytoplankton flora of two rivers in Southeast
Brazil - Paraibuna and Pomba Rivers, Minas Gerais. Revista Brasileira de Botânica, vol. 30, no. 3, p. 433-450.

DOUNG, TT., FEURTET-MAZAL, A., COSTE, M., DANG, DK. and BOUDOU, A., 2007. Dynamics of diatom colonization processes in some rivers influenced by urban pollution (Hanoi, Vietnam). Ecological Indictors, vol. 7, no. 4, p. 839-851.

EDWARDS, RW., BENSON-EVANS, K., LEARNE, MA., WILLIANS, P. and WILLIANS, R., 1972. A biological survey of river Toff. Journal of Water Polution Conontrol, vol. 71, no. 2, p. 144-166.

EDWARDS, R., 1995. The ecological basis for the management of water quality. In HARPER, DM. and FERGUSON, AJD. (Eds.). The Ecological Basis for River Management. New York: Wiley. p. 135-146.

FERNANDES, VO. and ESTEVES, FA., 2003. The use of indices for evaluating the periphytic community in two kinds of substrate in Imboassica lagoon, Rio de Janeiro, Brazil. Brazilian Journal of Biology $=$ Revista Brasileira de Biologia, vol. 63, no. 2, p. 233-243.

FINLAY, BJ., 2005. Are microbial eukaryotes the most specious group on the planet? Journal of Phycology, vol. 44, no. 1, p. 32-33.

FRYER, G., 1987. Quantitative and qualitative: numbers and reality in the study of living organisms. Freshwater Biology, vol. 17 , no. 1 , p. $177-189$.

GASSE, F., JUGGINS, S. and KHELIFA, LB., 1995. Diatombased transfer functions for inferring

past hydrochemical characteristics of African lakes. Palaeogeography, Palaeoclimatology and Palaeoecology, vol. 117, no. 1-2, p. 31-54.

GOMEZ, N. and LICURSI, M., 2001. The Pampean Diatom Index (IDP) for assessment of rivers and streams in Argentina. Aquatic Ecology, vol. 35, no. 9, p. 173-181.

HERMANY, G., LOBO, EA., SCHWARZBOLD, A. and OLIVEIRA, MA, 2006. Ecology of the

epilithic diatom community in a low-order stream system of the Guaíba hidrographical region: subsidies to the environmental monitoring of southern Brazilian aquatic systems. Acta Limnologica Brasiliensia, vol. 18, no. 1, p. 9-27.

JOHN, J., 1998. Diatoms: tools for bioassessment of river health. A model for south-western Australia. Perth: Water and Rivers Com. p. 388.

JOHN, J., 2000. Diatom prediction and classification system for urban streams. Canberra: Land and Water Resources Research and Development Corporation.

KARR, JR., 1991. Biological integrity: a long-neglected aspect of water resource management. Ecological Applications, vol. 1, no. 1, p. $66-84$

KATOH, K., 1992. A comparative study on some ecological methods of evaluation of water pollution. Environmental Science, vol. 5, no. 1, p. 91-98.

KELLY, MG. and WHITTON, BA., 1995. The trophic diatom index: a new index for monitoring eutrophication in rivers. Journal of Applied Phycology, vol. 7, no. 4, p. 433-444. 
KELLY, MG., 1995. Use of community-based indices to monitor eutrophication in European rivers. Environmental Conservation, vol. 25 , no. 1 , p. $22-29$.

KELLY,MG.,CAZAUBON,A.,CORING,E.,DELL'UOMO,A., ECTOR, L., GOLDSMITH. B., GUASCH, H., HÜRLIMANN, J., JARLMAN, A., KAWECKA, B., KWADRANS, J., LAUGASTE, R., LINDSTROM, EA., LEITAO, M., MARVAN, P., PADISÁK, J., PIPP, E., PRYGIEL, J., ROTT, E., SABATER, S., Van DAM, H. and VIZINET, J., 1998. Recommendationsfor the routine sampling of diatoms for water quality assessments in Europe. Journal of Applied Ecology, vol. 10, no. 2, p. 215-224.

KOBAYASI, H. and MAYAMA, S., 1989. Evaluation of river water quality by diatoms. The Korean Journal of Phycology, vol. 4 , no. 2, p. 121-133.

KOLKWITZ, R. and MARSSON, M., 1908. Orologie der pflanzilichen saprobien. Ben Deustsh Botan Gen, vol. 26, n. 3., p. 505-519.

LANGE-BERTALOT, H. 1979. Pollution tolerance of diatoms as a criterion for water quality estimation. Nova Hedwigia Beiheft, vol. 64, no. 1, p. 285-304.

De LA-REY, PA., ROUX, H., RENSBURGL, L. Van and VOSLOO, A., 2008. On the use of diatom-based biological monitoring Part 2: A comparison of the response of sass 5 and diatom indices to water quality and habitat variation). Water $S A$, vol. 34 , no. 1, p. 61-69.

De LA-REY, PA., TAYLOR, JC., LAAS, A., RENSBURG, L. Van and VOSLOO, A., 2004. Determining the possible application value of diatoms as indicators of general water quality: a comparison with SASS 5. Water SA, vol. 30, no. 3, p. $325-332$.

LAVOIE, I., CAMPEAU, S., DARCHAMBEAU, F., CABANA, G. and DILLON, PJ., 2008. Are diatoms good integrators of temporal variability in stream water quality? Freshwater Biology, vol. 53, no. 4, p. 827-841.

LECLERQ, L. and MAQUET, B., 1987. Deux nouveaux indices chimique et diatomique de qualité d'eau courante. Application au Samson et à ses afuents (bassin de la Meuse belge). Comparaison avec d'autres indices chimiques, biocénotiques et diatomiques. Brussels: Institut Royal des Sciences Naturelles de Belgique. (Document de travail no. 28).

LIEBMANN, CJ., 1951. Handbuch der Frishwasser und Abwasserbiologie. München: Oldenbourg Verlag.

LOBO, EA. and TORGAN, LC., 1988. Análise da estrutura da comunidade de diatomáceas (Bacillariophyceae) em duas estações do sistema Guaíba, RS, Brasil. Acta Botânica Brasílica, vol. 1 , no. 2 , p. 103-119.

LOBO, EA. and KOBAYASI, H., 1990. Shannon's diversity index applied to some freshwater diatom assemblages in the Sakawa River system (Kanagawa Pref., Japan) and its use as an indicator of water quality. Japanese Journal of Phycology, vol. 38, no. 2, p. 229-243.

LOBO, EA., OLIVEIRA, MA., NEVES, MT. and SCHULER, S. 1991. Caracterização de ambientes de terras úmidas, no Estado do Rio Grande do Sul, onde ocorrem espécies de anatídeos com valor cinegético. Acta Biológica Leopoldensia, vol. 13 , no. 1, p. 19-60.

LOBO, EA., KATOH, K. and ARUGA, Y., 1995a. Response of epilithic diatom assemblages to water pollution in rivers in the
Tokyo metropolitan area, Japan. Freshwater Biology, vol. 34, no. 1, p. 191-204.

LOBO, EA., 1995b. Avaliação da qualidade das águas doces continenatis utilizando Diatomáceas: uma proposta para o intercâmbio tecnológico e científico entre Brasil e Japão. Abstract. In Concurso Nacional de Monografias. São Paulo: USP. (Edição bilíngüe português-japonês).

LOBO, EA., CALLEGARO, VLM., OLIVEIRA, MA., SALOMONI, SE., SCHULER, S. and ASAI, K., 1996. Pollution tolerant diatoms from lotic systems in the Jacui Basin, Rio Grande do Sul, Brasil. Iheringia Série Botânica, vol. 47, no. 1, p. $45-72$.

LOBO, EA., BEM, DA., COSTA, A. and KIRST, A., 1999. Avaliação da qualidade da água dos arroios Sampaio, Bonito e Grande, Município de Mato Leitão, RS, Brasil, segundo a resolução do CONAMA 20/86. Revista Redes, vol. 4, no. 2, p. $129-146$

LOBO, EA. and CALLEGARO, VL., 2000. Avaliação da qualidade de águas doces continentais com base em algas diatomáceas epilíticas: enfoque metodológico. In TUCCI, CEM. and MARQUES, DM. (Eds.). Avaliação e controle da drenagem urbana. Porto Alegre: Universidade Federal do Rio Grande do Sul. p. 277- 300.

LOBO, EA., CAlLEGARO, VL. and BENDER, P., 2002. Utilização de algas diatomáceas epilíticas como indicadoras da qualidade da água em rios e arroios da Região Hidrográfica do Guaíba, RS, Brasil. Santa Cruz do Sul: EDUNISC. p. 127.

LOBO, EA., WETZEL, CE. and BES, D. 2003. Avaliação da qualidade da água dos arroios Sampaio, Bonito e Grande, Municípío de Mato Leitão, RS, Brasil. Revista Tecno-Lógica, vol. 7, no. 1, p. 39-53.

LOBO, EA., CALLEGARO, VL., HERMANY, G., BES, D., WETZEL, CE. and OLIVEIRA, MA., 2004a. Use of epilithic diatoms as bioindicator from lotic systems in southern Brazil, with special emphasis on eutrophication. Acta Limnologica Brasiliensia, vol. 16, no. 1, p. 25-40.

LOBO, EA., CALLEGARO, VL., HERMANY GOMEZ, N. and ECTOR, L., 2004b. Review of the use of microalgae in South America for monitoring rivers, with special reference to diatoms. Vie et Milieu, vol. 53, no. 1, p. 35-45,

LOBO, EA., BES, D., TUDESQUE, L. and ECTOR, L. 2004c. Water quality assessment of the Pardinho River, RS, Brazil, using epilithic diatom assemblages and faecal coliforms as biological indicators. Vie et Milieu, vol. 53, p. 46-53.

LOBO, EA., CALLEGARO, VL., WETZEL, CE., HERMANY, G. and BES, D., 2004d. Water quality study of Condor and Capivara streams, Porto Alegre municipal district, RS, Brazil, using epilithic diatoms biocenoses as bioindicators. Oceanological and Hydrobiological Studies, vol. 33, no. 1, p. 77-93.

LOBO, EA., CALLEGARO, VLM., HERMANY, G., BES, D., WETZEL, C. and OLIVEIRA, MA., 2004e. Utilização de algas diatomáceas como indicadores de eutrofização em sistemas aquáticos sul brasileiros. In Anais do Workshop Bioindicadores de Qualidade da Água. São Paulo: EMBRAPA. (CD-ROM).

LOBO, EA., SALOMONI, S., ROCHA, O. and CALLEGARO, VL., 2006. Epilithic diatoms as indicatores of water quality in the Gravataí river, Rio Grande do Sul, Brazil. Hydrobiologia, vol. 559, no. 1-2, p. 233-246. 
LOEZ, CR. and TOPALIAN, ML., 1999. Use of algae for monitoringrivers in Argentina with a special emphasis for Reconquista River (region of Buenos Aires). In PRYGIEL, J., WHITTON, BA. and BUKOWSKA, J. (Eds.). Use of Algae for Monitoring Rivers III. Douai: Agence de l'Eau Artois-Picardie. p. $72-83$.

LOWE, RL. and PAN, Y., 1996. Benthic algal communities as biological indicators. In STEVENSON, RJ., BOTHWELL, ML., and LOWE, RL. (Eds.). Algal ecology: freshwater benthic ecosystems. San Diego: Academic Press. p. 705-739.

MANN, DG., 1999. The species concept in diatoms. Phycologia, vol. 38 , no. 3, p. 437-495.

MARKER, AFH. and WILLOUGHBY, LG., 1988. Epilithic and epiphytic algae in streams of contrasting $\mathrm{pH}$ and hardness. In ROUND, FE. (Ed.). Algae and the aquatic environment. Briston: Biopress. p. 312-325.

MICHELS-ESTRADA, A., 2003. Ökologie und Verbreitung von Kiesenalgen in Fließgewässern Costa Rica als Grundlage für eine biologische Gewässergüteberteilung in den Tropen. Dissertationes Botanicae, vol. 377, no. 1-2, p. 244 - 257

MOURA, AN., BITTENCOURT-OLIVEIRA, MC. and NASCIMENTO, EC., 2007. Benthic Bacillariophyta of the Paripe River estuary in Pernambuco state, Brazil. Brazilian Journal of Biology = Revista Brasileira de Biologia, vol. 67, no. 3, p. 393-401.

NECCHI Jr., O., BRANCO, LHZ. and BRANCO, CCZ., 2003. Ecological distribution of stream macroalgal communities from a drainage basin in the serra da canastra national park, minas gerais, southeastern Brazil. Brazilian Journal of Biology, vol. 63 , no. 1, p. 635-646.

NYGAARD, G., 1949. Hydrological studies of some Denish ponds and lakes II: the quotient hypothesis and some new or little known phytoplankton organisms. Det Kongelige Danske Videnskabernes Selskabs publikationer Biologiske Skrifter, vol. 71, no. 1, p. 1-297.

OLIVEIRA, MA., TORGAN, LC., LOBO, EA. and SCHARZBOLD, A., 2001. Association of periphytic diatom species of artificial substrate in lotic environments in the arroio sampaio basin, RS, Brazil: relationships with abiotic variables. Brazilian Journal of Biology, vol. 61, no. 4, p. 523-540.

PALMER, CM., 1969. A composite rating of algae tolerating organic pollution. Journal of Phycology, vol. 5, no. 1, p. 78-82.

PAN, Y., STEVENSON, RJ., HILL, BH., HERLIHY, AT. and COLLINS, GB., 1996. Using diatoms as indicators of ecological conditions in lotic systems: a regional assessment. Journal of North American Bethological Society, vol. 15, no. 4, p. $481-495$.

PANTLE, R. and BUCK, H., 1955. Die biologiscke uberwachung der gewasser rend die darstellung der ergebrisse. Gas und Wasserfach, vol. 96, p. 11-17.

PASSY. SI., 2007. Community analysis in stream biological monitoring: what must we measure and what we don't. Environmental Monitoring and Assessment, vol. 127, no. 1-3, p. 409-417.

PATRICK, R. and HENDRICKSON, J., 1993. Factors to consider in interpreting diatom changes. Nova Hedwigia Beihelf, vol. 106, p. 361-377.
PATRICK, R., 1953. Aquatic organisms as an aid in solving waste disporsal problems. Swage Industrial Wastes, vol. 25, no. 2 , p. 210-227.

PATRICK, R., 1986. Diatoms as indicators of changes in water quality. Philadelphia: Academy of Natural Sciences.

PATRICK, R., and REIMER, CW., 1966. The diatoms of the United States. Philadelphia: Academy of Natural Sciences. p. 688 .

PETERSON, CG. and STEVENSON, RJ., 1989. Seasonality in river phytoplankton: multivariate analyses of data from the Ohio River and six Kentucky tributaries. Hydrobiologia, vol. 182, no. 2, p. 99-114.

PIETERSE, AJH. and ZYL, JM. Van, 1988. Observations on the relation between phytoplankton diversity and environmental factors in the Vaal River at Balkfontein, South Africa. Hydrobiologia, vol. 169, no. 2, p. 199-207.

POTAPOVA, MG. and CHARLES, DF., 2002. Benthic diatoms in USA rivers: distributions along speciation and environmental gradients. Journal of Biogeography, vol. 29, no. 2, p. 167-187.

POTAPOVA, MG. and CHARLES, DF., 2003. Distribution of benthic diatoms in U.S. rivers in relation to conductivity and ionic composition. Freshwater Biology, vol. 48, no. 8, p. 1311-1328.

PRYGIEL, J. and COSTE, M., 1993. The assessment of water quality in the Artois-Picardie water basin (France) by the use of diatom indices. Hydrobiologia, vol. 269-270, no. 2, p. 343-349.

PRYGIEL, J., WHITTON, BA. and BUKOWSKA, J., 1999. Use of Algae for Monitoring Rivers III. Douai: Agence de L'eau Artois-Picardie. p. 271.

RESH, VH., 2007. Multinational, freshwater biological monitoring programs in the developing world: lessons learned from African and southeast Asian River Surveys. Environmental Management, vol. 39, no. 5, p. 737-748.

ROCHA, AA., 1992. Algae as indicatiors of water pollution. In CORDEIRO-MARINO, M., AZEVEDO, MTP., SANT'ANNA, CL., TOMITA, NY. and PASTINO, EM. (Eds.). Algae and environment: a general approach. São Paulo: Sociedade Brasileira de Ficologia; CETESB. p. 34-55.

ROTHFRITZ, H., JUTTNER, I., SUREN, AM. and ORMEROD, SJ., 1997. Epiphytic and epilithic diatom communities along environmental gradients in the Nepalese Himalaya: implications for the assessment of biodiversity and water quality. Archives für Hydrobiology, vol. 138, no. 3, p. 465-482.

ROSA, ZM., TORGAN, LC. and HERZOG, LAW., 1988. Análise da estrutura de comunidades fitoplanctônicas e de alguns fatores abióticos em trecho do Rio Jacuí, Rio Grande do Sul, Brasil. Acta Botanica Brasilica, vol. 2, no. 1, p. 31-46.

ROUND, FE., 1991. Diatoms in river water-monitoring studies. Journal of Applied Phycology, vol. 3, no. 1, p. 129-145.

ROUND, FE., 1993. A review and methods for the use of epilithic diatoms for detecting and monitoring changes in river water quality: methods for the examination of water and associated materials. London: HMSO Publications.

SALOMONI, SE. and TORGAN, LC., 2008. Epilithic diatoms as organic contamination degree indicators in Guabia Lake, southern Brazil. Acta Limnologica Brasiliensia, vol. 20, no. 3, p. 313-324. 
SALOMONI, SE., ROCHA, O., CALLEGARO, VL. and LOBO, EA., 2006. Eplithic diatoms as indicators of water quality in the Gravataí river, Rio Grande do Sul, Brazil. Hydrobiologia, vol. 559, no. 2, p. 233-246.

SALVIA, M., IFFLY, JF., BORGHT, PV., SARY, M. and HOFFMANN, L., 1999. Application of the 'snapshot' methodology to a basin-wide analysis of phosphorus and nitrogen at stable low flow. Hydrobiologia, vol. 410, p. 97-102.

SCHNECK, F., TORGAN, LC. and SCHWARZBOLD, A., 2007. Epilithic diatom community in a high altitude stream impacted by fish farming in southern Brazil. Acta Limnolica Brasiliensia, vol. 19 , no. 4, p. 341-355.

SCHOEMAN, FR. and HAWORTH, EY., 1986. Diatom as indicator of pollution. In Proceedings of the 8 International Diatom Symposium. Koenigstein: Koeltz Scientific Books. p. $757-766$

SCHOEMAN, FR., 1979. Diatoms as indicators of water quality in the upper Hennops River. Journal of the Limnological Society of South Africa, vol. 5, no. 2, p. 73-78.

SILVA-BENAVIDES, AM., 1996a. The use of water chemistry and benthic diatom communities for qualification of a polluted tropical river in Costa Rica. Revista de Biologia Tropical, vol. 44, no. 2, p. 395-416.

SILVA-BENAVIDES, AM., 1996b. The epilithic diatom flora of a pristine and a polluted river in Costa Rica, Central America. Diatom Research, vol. 11, no. 1, p. 105-142.

SLÀDECEK, V. 1973. System of water quality from the biological point of view. Archives für Hydrobiologie und Ergebnisse Limnologie, vol. 7, no. 1, p. 1-218.

SLÁDECÉK, V., 1986. Diatoms as indicators of organic pollution. Acta Hydrochimica et Hydrobiologica, vol. 14, no. 5, p. 555-566.

SLÁDECKOVA, A. and SLÁDECÉK, V., 1963. Periphyton as indicators of water quality. Technology of Water, vol. 7, no. 1, p. 507-561. (parte 1, True Periphyton).

SONNEMAN, JA., WALSH, CJ., BREEN, PF. and SHARPE, AK., 2001. Effects of urbanisation on streams of the Melbourne region, Victoria, Australia: II Benthic diatom communities. Freshwater Biology, vol. 46, no. 4, p. 553-560.

STEVENSON, RJ. and PAN, Y., 1999. Assessing environmental conditions in rivers and streams with diatoms. In STOERMER, EF. and SMOL, JP. (Eds.). The Diatoms: applications for the environmental and earth sciences. Cambridge: Cambridge University Press. p. 11-40.

STOERMER, EF. and SMOL, JP., 1999. The Diatoms: applications for the environmental and earth sciences. Cambridge: Cambridge University Press. p. 467.

TAYLOR, CJ., PRYGIEL, AV., LA-REY, PA. and RENSBURG, S. Van, 2007. Can diatom-based pollution indices be used for biological monitoring in SA? A case study of the Crocodile West and Marico water management area. Hydrobiologia, vol. 592, no. 1, p. 455-464.

THUNMARK, S., 1945.Zur soziologie der susswasserplanktons. Folia Limnologia. Scandinavia, vol. 3, no. 1, p. 1-66.

TUNDISI, JG., 2006. O futuro dos recursos hídricos no Brasil. Safari Air Emp. Ltda, Brazilia: Projeto Brasil das Águas. Available from: <http://www.brasildasaguas.com.br/>. Access in: $19 / 01 / 2010$.

TUNDISI, JG. and MATSUMURA-TUNDISI, T., 1993. Eutrophication of lakes and reservoirs: a comparative analysis, case studies, perspectives. In CORDEIRO-MARINO, M., AZEVEDO, MTP., SANT'ANNA, CL., TOMITA, NY. and PASTINO, EM. (Eds.). Algae and environment: a general approach. São Paulo: Sociedade Brasileira de Ficologia; CETESB. p. 1-33.

TUNDISI, JG. and MATSUMURA-TUNDISI, T., 2008. Limnologia. São Paulo: Câmara Brasileira do Livro.

WALMSLEY, RD., 2000. Perspectives on Eutrophication of Surface Waters: Policy/Research Needs in South Africa. Pretoria: Water Research Commission. (WRC Report no. KV129/00).

WATANABE, T., ASAI, K. and HOUKI, A., 1988. Numerical water quality monitoring of organic pollution using diatom assemblages. In Proceedings of the 9 International Diatom Symposium. Koenigstein: Koeltz Scientific Books. p. 123-141.

WEHR, JD. and DESCY, J., 1998. Use of phytoplankton in large river management. Journal of Phycology, vol. 36, no. 5, p. 741-749.

WINTER, JG. and DUTHEI, HC., 2000. Epilithic diatoms as indicators of stream total $\mathrm{N}$ and total $\mathrm{P}$ concentrations. Journal of North American Benthological Society, vol. 19, no. 1, p. 32-49.

ZELINKA, M. and MARVAN, P., 1961. Zur prasisiering der biologischen klassifikation der reinheot fliessender gewässer. Archive Hydrobiologia, vol. 57, no. 3, p. 389-407. 